\title{
UNDERSTANDING THE SELECTION OF VOCABULARY LEARNING STRATEGIES: THE IMPACT OF THE LANGUAGE TEACHING APPROACH
}

\author{
Irene Castellano Risco \\ Universidad de Extremadura \\ ircastellano@unex.es
}

\begin{abstract}
This paper presents a study on bow the selection of vocabulary learning strategies is affected by the kind of instructional programme followed. A total of one bundred thirty-eight secondary-school learners - seventy-two CLIL (Content and Language Integrated Learning) and fifty-six mainstream EFL (English as a Foreign Language) learners - took part in the study. They were asked to respond a vocabulary learning strategies questionnaire. The data were examined looking into bow the use of strategies differed when comparing CLIL and EFL learners. Results permitted to develop two clear learner profiles that were compared. These findings will be discussed in relation to their possible implications for vocabulary development.
\end{abstract}

Keywords: Vocabulary Learning Strategies, Content and Language Integrated Learning, English as a Foreign Language, secondary-school learners. 
IRENE CASTELLANO RISCO

\title{
LA SELECCIÓN DE LAS ESTRATEGIAS DE APRENDIZAJE DE LÉXICO: EL IMPACTO DE ENFOQUE DE ENSEÑANZA
}

\begin{abstract}
RESUMEN. Este estudio presenta un análisis sobre la influencia del programa de instrucción en la selección de estrategias de aprendizaje de léxico. Un total de ciento treinta y ocho alumnos de educación secundaria -setenta y dos alumnos AICLE (Aprendizaje Integrado de Contenidos y Lengua Extranjera) y cincuenta y seis alumnos de instrucción ILE (Inglés como Lengua Extranjera)-participaron en el estudio y respondieron un cuestionario sobre el uso de estrategias de aprendizaje de léxico. Los datos se analizaron con el objetivo de observar cómo el uso de estrategias difería en alumnos con perfiles de enseñanza distintos. Los resultados son discutidos en relación con su posible implicación en el desarrollo léxico.
\end{abstract}

Palabras clave: estrategias de aprendizaje léxico, Aprendizaje Integrado de Contenido y Lengua Extranjera, educación secundaria.

Received 10 October 2018

Revised version accepted 5 June 2019

\section{INTRODUCTION}

In the last 40 years, vocabulary has reached an unforeseen position within the field of Second Language Acquisition after years of grammar supremacy (Boers and Lindstromberg 2009; Meara 1980; Milton and Fitzpatrick 2014; Nation 2001; Schmitt 2010). Starting within the movement of regeneration towards exploring aspects other than grammar in language learning, vocabulary was considered central to mastering a second language. For this reason, a large body of research on aspects directly related to vocabulary learning, such as frequency (Coxhead 2000; Nation 2001; Schmitt 2010), testing (Laufer and Nation 1999; Meara 2010; Schmitt, Schmitt and Claphman 2001) or the implications of word knowledge (Anderson and Freebody 1981; Meara 1996a), has been carried out.

In this context, studies on vocabulary learning strategies emerged as a response to the need to understand how vocabulary is learnt. Language learning strategies had already been explored for nearly twenty years from a psycholinguistic perspective (Bialystok 1978; O'Malley and Chamot 1990; Oxford 1990) when they started to be applied to vocabulary. This field of study aimed at identifying the most beneficial actions or behaviours that language learners took when learning a new language and their findings had already materialized into a number of taxonomies and principles. Language learning strategies, and, consequently, vocabulary learning strategies, seem to be teachable actions and their selection seems to be influenced by a number of different aspects, such as the foreign language studied or the language learning approaches used. 
It is in line with this latter idea that the present study has been conceptualized, as it can clearly be used to approach the new language teaching proposals put forward in recent times. In the last fifteen years, a new language learning approach has come to Spain. This approach, known as Content and Language Integrated Learning (CLIL), promotes the use of a foreign language as a vehicle of communication in content subjects. To achieve full development of contents and language, new teaching techniques are proposed and new objectives are set. In the case of vocabulary learning, research has shown that the use of CLIL seems to benefit vocabulary development. Therefore, if there is a modification in the way language is conceived and this resonates with the vocabulary learnt, could it be that CLIL also affects the way learners learn vocabulary?

This paper is organized as follows. First, it deals with theoretical aspects regarding vocabulary learning strategies and their possible relation to CLIL, including a short account of what CLIL involves. After that, the methodology followed will be explained. To do so, the research questions, the sample, and the instruments will be detailed. Then, the data obtained from the Vocabulary Learning Strategies questionnaire (adapted from Schmitt 1997) are presented, administered to two groups of year 9 secondary school learners from Extremadura (a CLIL group and a mainstream EFL [English as a Foreign Language] group). These data are examined, looking at the difference in the selection of vocabulary learning strategies between both groups.

\section{LITERATURE REVIEW}

Since the 1990s, there has been substantial body of research on vocabulary learning strategies in the literature (e.g., Gu and Johnson 1996; Intaraprasert 2004; Jiménez Catalán 2003; Nation 2001; Schmitt 1997; Stöffer 1995). This area of research started to be conceptualized with the inclusion of the strategic competence as part of the communicative competence (Canale and Swain 1980; Canale 1983). In these years, and as a first approach to the concept, the strategic competence was conceived as the "verbal and non-verbal communication strategies that may be called into action to compensate for breakdowns in communication due to performance variables or to insufficient competence" (Canale and Swain 1980: 30). However, soon, this definition turned out to be insufficient due to the quick development of the field and a vast body of research that emerged revolving the concept of strategy (see, for example, O'Malley and Chamot 1990; Oxford 1989, 1990; Politzer 1983; Rubin 1987, Wenden 1991 or Wenden and Rubin 1987). The emergence of strategic competence studies in the language learning field gave impulse to the incorporation of a new term already explored from a psychological 
perspective, - the learning strategies-, to the language teaching research and resulted in a large number of empirical studies on language learning strategies (Bialystok 1978; O'Malley and Chamot 1990; Oxford 1990). That is, whereas in the beginning, the focus was on the term 'competence' itself, over the years, and more and more interest was placed on the term 'strategy' and research from other fields was incorporated to the language learning research. In this particular case, the concept 'strategy' no longer referred exclusively to the communicative dimension mentioned by Canale and Swain and to the tactics used to overcome lack of language when communicating, but it could make reference to other types of tactics or actions devoted to control the language learning processes (Martín Leralta 2006).

This new conception of strategies and the relevance it placed on how languages were learnt coincided in time with the new consideration of vocabulary learning as a key aspect to achieve a fully mastery of a foreign language (Laufer 1990; Meara 1980, 1996a, 1996b; Nation 1974; Richards 1976; Xue and Nation 1984) and vocabulary learning strategies resulted from this conjunction. Vocabulary learning strategies are usually defined as the "knowledge about the mechanisms (processes, strategies) used in order to learn vocabulary as well as the steps or actions taken by students (a) to find out the meaning of unknown words, (b) to retain them in long-term memory, (c) to recall them at will and (d) to use them in oral/written mode" (Jiménez Catalán 2003: 56). This definition brings together most of the agreements about what the concept of vocabulary learning strategies entails: (1) vocabulary learning strategies are part of the language learning strategies and (2) they are those actions that are used at least for (a) understanding what a new word means and (b) consolidating the word meanings (Cameron 2001; Intaraprasert 2004; Nation 2001). However, research on the area has not focused exclusively on the definition of the term and has explored different aspects: on the one hand, there have been numerous attempts to identify vocabulary learning strategies and classify them into taxonomies (Gu and Johnson 1996; Nation 2001; Schmitt 1997; Stöffer 1995). Among others, the most widely-used taxonomy is Schmitt's taxonomy (1997). It consists of a list of 58 strategies that was developed using three sources of information: Oxford's taxonomy of learning strategies (Oxford 1990), the research done with Japanese learners and some recommendations pointed out by teachers. In order to compile his taxonomy, the author first analysed a series of textbooks, and, after that, he asked Japanese intermediate level students to write a report on how they learned English vocabulary. They were also asked to review a preliminary list of strategies and add other strategies used. Finally, Schmitt organised the results using Oxford's taxonomy as a basis. As a result, six categories were established summarised in Table 1 and explained in detail thereafter: 
UNDERSTANDING THE SELECTION OF VOCABULARY LEARNING STRATEGIES...

Table 1. Schmitt's taxonomy (1997).

\begin{tabular}{|c|c|c|}
\hline \multirow{2}{*}{$\begin{array}{l}\text { Discovery } \\
\text { strategies }\end{array}$} & $\begin{array}{l}\text { Determination } \\
\text { strategies }\end{array}$ & $\begin{array}{l}\text { The way learners discover individually the } \\
\text { meaning of an unknown word }\end{array}$ \\
\hline & Social strategies & $\begin{array}{l}\text { Ways to discover new meanings by interacting } \\
\text { with others }\end{array}$ \\
\hline \multirow{4}{*}{$\begin{array}{l}\text { Consolidation } \\
\text { strategies }\end{array}$} & $\begin{array}{l}\text { Metacognitive } \\
\text { strategies }\end{array}$ & $\begin{array}{c}\text { "A conscious overview of the learning process } \\
\text { and making decisions about planning, monitoring } \\
\text { or evaluating the best ways to study" (Schmitt } \\
1997: 17)\end{array}$ \\
\hline & Memory strategies & $\begin{array}{l}\text { "Relating the word to be retained with some } \\
\text { previously learned knowledge, using some form } \\
\text { of imagery, or grouping" (Schmitt 1997: 15) }\end{array}$ \\
\hline & Cognitive strategies & $\begin{array}{l}\text { "Manipulation or transformation of the target } \\
\text { language by the learner" (Schmitt 1997: 16) }\end{array}$ \\
\hline & Social strategies & $\begin{array}{c}\text { Ways to discover new meanings by interacting } \\
\text { with others }\end{array}$ \\
\hline
\end{tabular}

Finally, other branch of research has attempted to understand the underpinning process in the selection of vocabulary learning strategies. The selection of language learning strategies, and, consequently, of vocabulary learning strategies, is acknowledged to be influenced by a number of factors related to learners' language background, learners' characteristics and the language teaching practice (Oxford and Nyikos 1989). Focusing on this latter aspect, two main aspects have been identified as determining in the selection of vocabulary learning strategies: the language task and the language teaching method.

There has been some research on the variation in the use of strategies when facing with different types of tasks. Bialystok (1981), a pioneer in the area, reported that learners used different strategies depending on the objective of the task, finding that some strategies only were considered as useful for certain activities. These results set precedent, and since then, there has been an increasing number of studies analysing the relationship between strategies and tasks devoted to the development of the four language skills: listening (Bacon 1992; Vandergrift 1997), reading (Barnett 1989; Hayati 2005), writing (Manchón 2001; Trenchs 1996) and speaking (Cohen, Weaver and Li 1998).

However, to the best of my knowledge, most emphasis has been placed on the influence of specific skill tasks while little research has been carried out exploring the impact of a more general aspect: the language teaching approach. 
It is in line with this latter idea that the present research study has been set out. In recent decades, a new language teaching approach has been implemented in Europe. This new set of methodologies, known as Content and Language Integrated Learning approach, that advocates the use of foreign languages when teaching content subjects has been introduced into Europe. This approach has revolutionized the teaching practice to unforeseen limits. In CLIL practices, the aim is no longer the language development itself, but developing a language in order to be able to transmit some academic contents. This new vision of language has particularly benefit the lexical development (Agustín-Llach and Canga Alonso 2016; Canga Alonso 2015). However, most research has focused on the vocabulary benefits, and has neglected the analysis of how the implementation of this approach affect the actions the learners take to learn vocabulary. Two main conclusions could be drawn with regards to vocabulary studies in Spain in the CLIL context in the last decade: first, when learners with the same age and different exposure to the foreign language (in favour of CLIL learners due to the larger exposure this approach promotes) were compared, it has been found that CLIL learners outperformed mainstream EFL learners (Agustín-Llach 2012; Arribas 2016, Castellano-Risco 2018). Nevertheless, when CLIL and mainstream EFL learners of different ages but with the same exposure to English were compared, CLIL learners did not show any superiority over mainstream EFL learners with regards the recognition of vocabulary items. Therefore, those studies which found a positive impact of CLIL on vocabulary size could not strictly demonstrate that such difference was related to the approach followed, as it could be also occasioned by a larger exposure to English CLIL learners received.

Similarly, this piece of research tackles the CLIL and EFL learners' differences in lexical development but from a different perspective: instead of exploring the final learning product (i.e., the vocabulary known), it aims to examine variations in the actions taken to learn vocabulary. Although some research has been carried out on CLIL learners' use of strategies (see, for example Martínez Adrián et al. 2019, or Azkarai and Imaz Aguirre 2016), to the best of my knowledge, in these previous attempts, strategies have been explored from a communicative perspective considering them actions to overcome lack of language knowledge rather than actions to facilitate language learning, so this study comes to fill the gap by exploring a new dimension: the vocabulary learning strategies.

\section{RESEARCH QUESTIONS}

RQ1: Do secondary-school learners show any preference for some specific vocabulary learning strategies? 
UNDERSTANDING THE SELECTION OF VOCABULARY LEARNING STRATEGIES...

RQ2: Does the selection of vocabulary learning strategies differ depending on the type of instruction learners are exposed to?

\section{METHOD}

\subsection{PARTICIPANTS}

The study took place in Extremadura, a monolingual region in Spain. CLIL programs started to be implemented in the academic year 2004/05 as a pilot program with the objective of promoting second language learning (for more detailed information, see Alejo González and Piquer Píriz 2010; Alejo and PiquerPíriz 2016).

A convenience sample of 138 secondary-school learners was analysed. All learners were in Year 9, with ages ranging from 14 to 16. Regarding gender, there were specifically 64 males and 74 females. The main difference among learners was related to the EFL program they attended. Seventy-two participants - 44 girls and 38 boys - were involved in CLIL programmes, whereas fifty-six students 26 boys and 30 girls - attended mainstream English as Foreign Language subject. Participants came from four different secondary state schools in Badajoz and main differences between them were not related to the Socio-Economic Status, age, or gender, but to the language teaching approach to which they are exposed and the number of hours of instructions they receive in English. Mainstream EFL participants were exposed to EFL classes a mean of three times a week for ten academic years, whereas in the case of CLIL participants, like mainstream EFL learners, they started EFL classes at the age of three, but then their exposure increased due to the attendance to content subjects in English for a mean time of five years. Due to this difference in the amount of input, CLIL learners were exposed to a mean of 2400 hours of English, whereas in the case of mainstream EFL participants, they presented an amount of English input of approximately, 1,200 hours.

\subsection{INSTRUMENT}

A Vocabulary Learning Strategies questionnaire was used in this study. This questionnaire was designed by adapting Schmitt's taxonomy of vocabulary learning strategies (1997). This taxonomy was selected for various reasons, but mainly because it provided a wide range of strategies and it was compiled using secondary-school learners. However, it also presented some shortcomings. Schmitt's taxonomy was made up of 58 strategies, clustered into six main groups: determination, social for discovering meanings, social for consolidating meanings, 
cognitive, metacognitive and memory. Developing a questionnaire with such a large number of items and asking secondary-school learners to answer it was excessive, bearing in mind learners' attention span at this age.

Thus, an adaptation of the taxonomy was needed and two main criteria were established: (1) the questionnaire was developed in Spanish in order to facilitate and make sure understanding on the part of students, and (2) it was important for the proportion of items in each category to remain unchanged. In order maintain this, firstly, the strategies in each category were counted and the intended total number of items was established. After that, the new number of items per category was calculated from the following equation, in which fifty-eight corresponds to the total number of items included in Schmitt's proposal and twenty-one represents the total number of items that are wanted to be included in the questionnaire.

$$
\frac{\text { No. of items of this category }}{58}=\frac{X}{21}
$$

In order to select the strategies in each category, those strategies that had demonstrated greater use in other studies in which the usage of vocabulary learning was analysed, were included (García López 2000; Gu and Johnson 1996; Lawson and Hogben 1996; Schmitt 1997). Moreover, there were some strategies based on specific methods such as the PEG ${ }^{1}$, the $\mathrm{LOCI}^{2}$ or the KEYword ${ }^{3}$ method, that were directly omitted, as those methods were completely unknown to the sample. Finally, the questionnaire was piloted to ensure its suitability for students of this age, and some of the questions had to be reformulated. As a result, the final questionnaire was made up of twenty-one strategies in which test-takers had to mark their use of each strategy on a Likert scale from 1 (never) to 4 (always).

\subsubsection{Construct validity}

Ehrman, Leaver and Oxford (2003) assert that success of vocabulary learning strategies is not related to frequency of use, but to how they are combined with

\footnotetext{
1 The PEG method is a practice that consists on linking words that have no sense relationships by connecting the words to pictures, letters, sounds or numbers in order to be able to recall them (Schmitt 1997).

2 In Schmitt's words (1997: 13) "in the Loci Method, one recalls a familiar place, such as a street, and mentally places the first item to be recalled in the first location, the second item in the second location, and so on. To recall the items, one mentally proceeds along the landmarks and retrieves the items which have been associated with each location".

3 "The Keyword Method entails a learner finding a L1 word which sounds like the target L2 word, i.e. the English word cat for the Japanese word katana (sword). Then an image combining the two concepts is created, such as a samurai cat waving a sword. When the L2 word is later heard, the sound similarity invokes the created image which prompts the L2 word's meaning" (Schmitt 1997: 15).
} 
Table 2. Items included in the questionnaire.

\begin{tabular}{|c|c|c|}
\hline Group & Sub-group & Strategies \\
\hline \multirow{8}{*}{$\begin{array}{l}\text { Discovery } \\
\text { strategies }\end{array}$} & \multirow{5}{*}{$\begin{array}{l}\text { Determination } \\
\text { strategies }\end{array}$} & Analysing part of speech \\
\hline & & Analysing affixes and roots \\
\hline & & Check for L1 cognate \\
\hline & & Analysing any available picture or gesture \\
\hline & & Using a bilingual dictionary \\
\hline & \multirow{3}{*}{ Social strategies } & Asking teacher for an L1 translation \\
\hline & & $\begin{array}{l}\text { Asking teacher for paraphrase or a synonym of a } \\
\text { new word }\end{array}$ \\
\hline & & Asking students for meaning \\
\hline \multirow{13}{*}{$\begin{array}{l}\text { Consolidation } \\
\text { strategies }\end{array}$} & Social strategies & Studying and practice meaning in group \\
\hline & \multirow{6}{*}{ Memory strategies } & $\begin{array}{l}\text { Studying word with a pictorial representation of its } \\
\text { meaning }\end{array}$ \\
\hline & & Connecting word to a personal experience \\
\hline & & $\begin{array}{l}\text { Connecting the word to its synonyms and } \\
\text { antonyms }\end{array}$ \\
\hline & & Using a new word in a sentence \\
\hline & & Grouping words together to study them \\
\hline & & Using physical action when learning a word \\
\hline & \multirow{3}{*}{ Cognitive strategies } & Verbal repetition \\
\hline & & Written repetition \\
\hline & & Word lists \\
\hline & \multirow{3}{*}{$\begin{array}{l}\text { Metacognitive } \\
\text { strategies }\end{array}$} & Using English-language media \\
\hline & & Skipping or passing on a new word \\
\hline & & Continuing to study a word over time \\
\hline
\end{tabular}

other strategies. In other words, an appropriate combination of strategies seems to produce a positive effect on language learning. It is in this vein that the analysis of the subgroups of strategies makes sense. But, Oxford (2017: 6857) states that learning strategies can be "combine[d] in various ways". Based on this idea, it seemed that a more profound exploration of the internal coherence of each group was needed, in order to check whether the sample of this study grouped strategies in the same way than Schmitt's proposed.

For that reason, a Cronbach's coefficient Alpha analysis was carried out to explore the groups of strategies in general, and then, to explore the particular groups 
proposed by Schmitt (1997). As for the whole group of strategies, results showed a general Cronbach's coefficient of 0.69 . This was quite near to the accepted value (0.7; Nunnaly 1978), and therefore, it could be claimed that the data presented internal coherence. In contrast, the results regarding the different sub-groups presented by Schmitt did not show any internal coherence within each group.

In light of the results, the present classification might not represent the way the present sample is grouping the vocabulary learning strategies. To the best of my knowledge, there are no studies attesting the utility and reliability of the classification proposed by Schmitt (1997). For this reason, there was a need to analyse the use of strategies looking for a statistical relationship between them. To serve this purpose, a factor analysis was carried out. The factor analysis is a mathematically complex procedure that reduces a correlation matrix containing many variables into much smaller number of factors. The aim was to find out whether the strategies could be grouped according to their use. As can be seen in Table 3, eight main factors were identified:

Table 3. Groups identified in the factor analysis.

\begin{tabular}{|c|c|c|c|}
\hline Group & Explanation & Strategies & $\begin{array}{l}\text { Factor } \\
\text { Loading }\end{array}$ \\
\hline \multirow{6}{*}{$\begin{array}{l}\text { Lexical } \\
\text { analysis } \\
\text { strategies }\end{array}$} & \multirow{6}{*}{$\begin{array}{l}\text { Renamed as 'lexical } \\
\text { analysis' group, it } \\
\text { encompasses all those } \\
\text { strategies were closely } \\
\text { related to the lexical } \\
\text { acquisition }\end{array}$} & Analysing part of the speech & .639 \\
\hline & & Analysing affixes and roots & .693 \\
\hline & & Using new words in a sentence & .375 \\
\hline & & $\begin{array}{c}\text { Grouping words together to study } \\
\text { them }\end{array}$ & .421 \\
\hline & & Connecting the word to its synonyms & .443 \\
\hline & & Using English-Language media & .334 \\
\hline \multirow{3}{*}{$\begin{array}{l}\text { Mental } \\
\text { imagery }\end{array}$} & \multirow{3}{*}{$\begin{array}{l}\text { These strategies } \\
\text { concerned vocabulary } \\
\text { learning through } \\
\text { linking of meaning to } \\
\text { concrete things such } \\
\text { as pictures or personal } \\
\text { experiences }\end{array}$} & $\begin{array}{l}\text { Studying the word with pictorial } \\
\text { representation }\end{array}$ & .989 \\
\hline & & Analysis of pictures and gestures & .561 \\
\hline & & $\begin{array}{l}\text { Connecting word to a personal } \\
\text { experience }\end{array}$ & .303 \\
\hline \multirow{2}{*}{ Repetition } & \multirow{2}{*}{$\begin{array}{l}\text { Strategies implied } \\
\text { repetition actions in } \\
\text { any form: written or } \\
\text { spoken }\end{array}$} & $\begin{array}{c}\text { Saying a new word aloud when } \\
\text { studying }\end{array}$ & .573 \\
\hline & & Written repetition & .847 \\
\hline
\end{tabular}




\begin{tabular}{|c|c|c|c|}
\hline \multirow{2}{*}{ Linking } & \multirow{2}{*}{$\begin{array}{l}\text { Strategies involved the } \\
\text { creation of links with } \\
\text { other words }\end{array}$} & Word lists & .865 \\
\hline & & Using a bilingual dictionary ${ }^{4}$ & .317 \\
\hline Kinaesthetic & $\begin{array}{c}\text { This group included } \\
\text { strategies that } \\
\text { has a kinaesthetic } \\
\text { component }\end{array}$ & $\begin{array}{l}\text { Using physical action when learning } \\
\text { a word }\end{array}$ & .992 \\
\hline \multirow[b]{2}{*}{$\begin{array}{c}\text { Guessing } \\
\text { from context }\end{array}$} & \multirow{2}{*}{$\begin{array}{c}\text { This group } \\
\text { encompasses } \\
\text { strategies that require } \\
\text { context information } \\
\text { to understand the } \\
\text { meaning of the words }\end{array}$} & Skipping or passing on new words & .350 \\
\hline & & Checking for L1 cognates 5 & .787 \\
\hline \multirow{2}{*}{$\begin{array}{c}\text { Social } \\
\text { strategies } \\
\text { involving } \\
\text { teacher } \\
\text { interaction } \\
\end{array}$} & \multirow{2}{*}{$\begin{array}{l}\text { This group presents } \\
\text { a close link to the } \\
\text { social strategies, but it } \\
\text { only focused on the } \\
\text { teachers' role }\end{array}$} & Asking teacher for an L1 translation & .643 \\
\hline & & $\begin{array}{l}\text { Asking teachers for paraphrasing or for } \\
\text { a synonym }\end{array}$ & .440 \\
\hline $\begin{array}{l}\text { Social } \\
\text { strategies } \\
\text { involving } \\
\text { students } \\
\text { interaction } \\
\end{array}$ & $\begin{array}{l}\text { This group is related } \\
\text { to the understanding } \\
\text { of new words aided } \\
\text { by other learners }\end{array}$ & Asking students for meaning & .727 \\
\hline
\end{tabular}

${ }^{4}$ Although at first glance the strategy 'checking in the bilingual dictionary' may not fit in this group, its inclusion was explained by the fact that students were asked to write down the vocabulary they looked up in the dictionary.

${ }^{5}$ At first sight, the strategy "skipping or passing new words" may not seem to be a guessing strategy, but it is the way it was expressed in the questionnaire which allowed to consider it as part of this group, as it is emphasized that the word is skipped when learners understand the gist of the text.

\section{RESULTS}

In this section, I will proceed by looking at the different aspects involved in the selection of vocabulary learning strategies. First, I will attempt to provide a clear picture of the selection and use of the strategies. Finally, I will look for differences between CLIL and mainstream EFL learners.

\subsection{RQ1: DO SECONDARY-SCHOOL LEARNERS SHOW ANY PREFERENCE FOR SOME SPECIFIC VOCABULARY LEARNING STRATEGIES?}

Once the framework of analysis has been determined, in this section, the selection of the vocabulary learning strategies - individually and by categories- 
is explored. To facilitate the analysis, the focus will be placed first on use of each strategies and then, I will move on to the group of strategies analysis.

\subsubsection{Use of each strategy}

Starting with the use of each strategy as an individual item, table 4 reveals, based on the mean frequency score, a clear picture of the secondary-school learners' reported use of the nineteen items. Starting with the top-three preferred strategies, it can be observed that learners' preferred strategy is 'checking for L1 cognate' (3.13), a lexical analysis strategy according to the analysis framework, followed by the 'use of wordlists' (3.04), a linking strategy, whereas in the third position the 'analysing affixes and roots' (2.90), included in lexical analysis, is found.

At the top of the table 4, three strategies are reported to be employed at the low frequency level: the 'use of physical action when learning a word' (1.30), followed by the 'connection of the word to a personal experience' (1.75) and 'asking the teacher for paraphrasing or for a synonym of the new word' (1.99). The least-preferred strategy corresponds to the kinaesthetic group, the second least strategy is a mental imagery group and the third least-used strategy is included in two different groups: lexical analysis and social involving teachers' actions strategies.

These results seem to point to the preference towards using lexical analysis and linking strategies. These strategies involve learners' reflection on the language properties and on how words interact. Some authors (Schmitt 1995) suggests that one of the most relevant aspects of the lexical competence is the development of the word's semantic network of associations and the selection of these strategies seems to be oriented to achieve this goal. On the other hand, results also show that kinaesthetic strategies are the least widely used. Different reasons, such as the learners' level of L2 proficiency, or the methodology employed in the EFL classes, could be attributed to this fact. In order to provide a more thorough explanation about these findings, these ideas will be taken up again in the discussion section.

\subsubsection{Use of the groups of strategies}

In the analysis of the selection of the groups of strategies, the least widely-used group corresponds to the 'kinaesthetic strategies' (1.29), which are reported to be used on a low level. There is an extreme contrast between the use of this group and the others, which nearly doubled this result. The preferred group is 'linking strategies' (2.78), that is, those strategies which involve creating links with other words, either 
Table 4. Use of vocabulary learning strategies.

\begin{tabular}{|l|c|c|}
\hline \multicolumn{1}{|c|}{ Strategies } & $\begin{array}{c}\text { Mean Frequency } \\
\text { score }\end{array}$ & $\begin{array}{c}\text { Standard } \\
\text { Deviation } \\
\text { (SD) }\end{array}$ \\
\hline Using physical action when learning a word & 1.30 & .624 \\
\hline Connecting a word to a personal experience & 1.75 & .823 \\
\hline $\begin{array}{l}\text { Asking teacher for paraphrasing or a synonym } \\
\text { of new word }\end{array}$ & 1.99 & .940 \\
\hline $\begin{array}{l}\text { Connecting the word to its synonyms and } \\
\text { antonyms }\end{array}$ & 2.19 & .931 \\
\hline Skipping or passing on a new word & 2.21 & .898 \\
\hline $\begin{array}{l}\text { Studying a word with a pictorial representation } \\
\text { of its meaning }\end{array}$ & 2.40 & .937 \\
\hline Verbal repetition & 2.40 & 1.031 \\
\hline Using a bilingual dictionary & 2.41 & .956 \\
\hline Written repetition & 2.46 & 1.053 \\
\hline Asking students for meaning & 2.58 & .835 \\
\hline Using a new word in a sentence & 2.61 & 1.080 \\
\hline Grouping words together to study them & 2.61 & .993 \\
\hline Using English-language media & 2.64 & 1.059 \\
\hline Analysing a part of speech & 2.66 & .932 \\
\hline Analysing any available picture or gesture & 2.74 & .984 \\
\hline Asking teacher for an L1 translation & 2.78 & .774 \\
\hline Analysing affixes and roots & 2.90 & .984 \\
\hline Word lists & 3.04 & .962 \\
\hline Checking for L1 cognate & 3.13 & \\
\hline
\end{tabular}

in English or Spanish, in order to retain the meaning of new target words. This group is followed by 'guessing from context' strategies (2.68), which embraces those strategies that are used to understand what an unknown word means by connecting it to the target language or by inferring the gist of the text without knowing all the specific words. Table 5 below shows the mean use of each group.

In this section, secondary-school learners' use of the different vocabulary learning strategies categories has been presented. In general, secondary-school learners showed a strong affinity for the use of linking strategies, those involving 
Table 5. Use of strategy groups.

\begin{tabular}{|l|c|c|}
\hline \multicolumn{1}{|c|}{ Group } & Mean Frequency score & $\begin{array}{c}\text { Standard Deviation } \\
\text { (SD) }\end{array}$ \\
\hline Kinaesthetic strategies & 1.29 & 0.62 \\
\hline Mental imagery strategies & 2.30 & 1.00 \\
\hline $\begin{array}{l}\text { Social strategies involving } \\
\text { teachers }\end{array}$ & 2.38 & 0.94 \\
\hline Repetition strategies & 2.43 & 1.04 \\
\hline Lexical analysis strategies & 2.55 & 1.00 \\
\hline $\begin{array}{l}\text { Social strategies involving } \\
\text { students }\end{array}$ & 2.58 & 0.84 \\
\hline Guessing from context strategies & 2.68 & 1.00 \\
\hline Linking strategies & 2.78 & 1.04 \\
\hline
\end{tabular}

the creation of links, and guessing strategies, that involve aids from the context. As already mentioned, this finding could be related to the task, i.e., learning vocabulary items, and to the different dimensions that word knowledge involves. In contrast, they systematically ignored the use of kinaesthetic strategies to remember new meanings.

These results help to establish a general profile of use. On the one hand, secondary-school learners show a preference towards lexical strategies, and it is reflected in both, the individual and group analysis of the strategies. On the other hand, they show a hostility towards using kinaesthetic strategies. In the following section, it will be explored whether the CLIL and EFL learners' selection of strategies differed and to what extent they differed from the general profile.

\subsection{RQ2: DO CLIL AND EFL LEARNERS' SELECTION OF VOCABULARY LEARNING STRATEGIES DIFFER?}

The aim of this section is to explore the impact of using CLIL on the selection of vocabulary learning strategies the participants make. To do so, in this section, differences with regard to selection of each strategy, first, and, then, of the different groups between CLIL and EFL participants will be explored.

In general, CLIL and EFL learners differ in the selection of vocabulary learning strategies. CLIL learners make greater use of strategies than EFL learners. In the 
UNDERSTANDING THE SELECTION OF VOCABULARY LEARNING STRATEGIES...

case of CLIL participants, the mean of use is 2.48, whereas EFL informants' mean of use is 2.42. Although this difference is not significant according to the results of the U-Mann Whitney test, there are more discrepancies between both groups. For example, as can be seen in table 5 below, their preferred strategies and those they used least do not match.

\subsubsection{Individual use of strategies}

As for the analysis of the use of each strategy, starting with the three preferred strategies, in general, the preferred strategy is the 'checking for L1 cognate'. Nevertheless, when examining CLIL and EFL informants' preferred strategy, they do not match: mainstream EFL learners prefer the use of word lists (3.43), whereas in the case of CLIL participants, there is a tie in this position among two strategies: the 'analysis of affixes and roots' (3.21) and 'checking for L1 cognate' (3.21). As for the second preferred strategy, in the overall results this is 'analysis of affixes and roots' (2.9), but it does not match either with the concrete selection of CLIL and EFL learners. Bearing in mind the tie in the first position in the case of CLIL learners, it can be considered that the strategy 'checking for L1 cognate' is the second preferred for both groups, although CLIL learners make greater use of this strategy (3.21) in comparison to EFL learners (3.02). Hence, it does not match with the general preference, in which the 'analysis of affixes and roots' has the second highest use. To complete the analysis of the top-three strategies, the two groups do not share the third most widely selected strategy and this strategy does not match with the overall preference. In general, the third preferred strategy is 'use of word lists' (3.04), but it is 'use of English-language media' (2.78) for CLIL participants, whereas for EFL learners it is 'grouping words together to study them' (2.82).

Differences regarding usage of vocabulary learning strategies are beyond the top-three strategies. In general, it can be stated that CLIL learners have a greater use of the following strategies: 'analysing the part of the speech', 'analysing of affixes and roots', 'checking for L1 cognate' 'using a bilingual dictionary', 'asking teacher for paraphrasing or a synonym of a new word', 'asking students for meaning', 'connecting a word to a personal experience', 'verbal repetition', 'using English-language media', and 'skipping or passing on a new word'. However, significant differences are only found in the selection of five strategies: CLIL learners make significant greater use of the 'analysis of affixes and roots' $(p=.000)$; the 'connection of the word to its synonyms and antonyms' $(p=.015)$ and the 'use of English-language media' $(p=.050)$, whereas EFL participants select significantly more often strategies related to 'written repetition' ( $p=.022)$ and 'use of word lists' $(p=.000)$. Table 6 below shows the CLIL and EFL learners' mean use of each strategy. 
Table 6. CLIL and EFL learners' mean use of strategies.

\begin{tabular}{|c|c|c|c|c|}
\hline Strategy & $\begin{array}{c}\text { CLIL } \\
\text { learners' } \\
\text { mean of } \\
\text { use }\end{array}$ & $\begin{array}{l}\text { EFL learners' } \\
\text { mean of use }\end{array}$ & $\begin{array}{c}P \\
\text { value }\end{array}$ & $\begin{array}{l}\text { Significant } \\
\text { difference }\end{array}$ \\
\hline Analysing part of speech & 2.73 & 2.55 & .343 & \\
\hline Analysing affixes and roots & 3.21 & 2.45 & .000 & $*$ \\
\hline Checking for L1 cognate & 3.21 & 3.02 & .174 & \\
\hline $\begin{array}{l}\text { Analysing any available picture or } \\
\text { gesture }\end{array}$ & 2.68 & 2.80 & .388 & \\
\hline Using bilingual dictionary & 2.44 & 2.36 & .590 & \\
\hline Asking teacher for an L1 translation & 2.77 & 2.79 & .955 & \\
\hline $\begin{array}{l}\text { Asking teacher for paraphrasing or } \\
\text { a synonym of a new word }\end{array}$ & 2.06 & 1.89 & .301 & \\
\hline Asking students for meaning & 2.67 & 2.45 & .122 & \\
\hline $\begin{array}{l}\text { Studying word with a pictorial } \\
\text { representation of its meaning }\end{array}$ & 2.36 & 2.45 & .531 & \\
\hline $\begin{array}{l}\text { Connecting word to a personal } \\
\text { experience }\end{array}$ & 1.79 & 1.69 & .461 & \\
\hline $\begin{array}{l}\text { Connecting the word to its } \\
\text { synonyms and antonyms }\end{array}$ & 2.35 & 1.96 & .015 & $*$ \\
\hline Using a new word in a sentence & 2.41 & 2.5 & .284 & \\
\hline $\begin{array}{l}\text { Grouping words together to study } \\
\text { them }\end{array}$ & 2.68 & 2.82 & .284 & \\
\hline $\begin{array}{l}\text { Using physical action when } \\
\text { learning a word }\end{array}$ & 1.28 & 1.32 & .518 & \\
\hline Verbal repetition & 2.41 & 2.39 & .978 & \\
\hline Written repetition & 2.29 & 2.70 & .022 & $*$ \\
\hline Word lists & 2.76 & 3.43 & .000 & $*$ \\
\hline Using English-language media & 2.78 & 2.45 & 0.50 & $*$ \\
\hline $\begin{array}{l}\text { Skipping or passing on a new } \\
\text { word }\end{array}$ & 2.30 & 2.09 & .161 & \\
\hline
\end{tabular}

\subsubsection{Use of the groups of strategies}

In addition, differences when exploring the new factors and categories are also found. As can be seen in Table 7, CLIL learners' preferred group of 
strategies is 'guessing from contexts strategies' (2.76), while for EFL learners, the preferred group is linking strategies (2.87). They do not share either the second preferred group: for CLIL learners it is 'linking strategies' group (2.72), whereas for EFL participants it is 'guessing from context' group (2.55). Nevertheless, they share the least preferred strategies: the kinaesthetic group, although EFL learners present a slightly (non-significant) higher use (2.32) in comparison with their CLIL counterparts (2.28).

All in all, CLIL learners make greater use of lexical analysis, guessing from context strategies and social strategies involving interaction with both teachers and students. On the other hand, EFL learners make greater use of mental imagery, repetition, linking and kinaesthetic strategies. However, differences are only significant in the case of strategies involving lexical analysis $(p=.000)$. Table 7 shows the CLIL and EFL learners' mean use of each group.

A number of implications can be drawn from this analysis. Among other findings, the results obtained tend to show that CLIL students reflect more on the properties of language than EFL learners. Moreover, they also seem to make greater use of social strategies. This finding is expected, as CLIL advocates for the use of interactive and cooperative learning situations, which can lead into a greater use of social strategies. Finally, EFL learners make greater use of repetition strategies. These and other findings will be discussed in depth in the following section.

Table 7. Differences between CLIL and EFL learners' selection of strategies grouped.

\begin{tabular}{|l|c|c|c|c|}
\hline \multicolumn{1}{|c|}{ Group } & $\begin{array}{c}\text { CLIL } \\
\text { learners }\end{array}$ & $\begin{array}{c}\text { EFL } \\
\text { learners }\end{array}$ & P value & $\begin{array}{c}\text { Significant } \\
\text { difference }\end{array}$ \\
\hline Lexical analysis strategies & 2.68 & 2.36 & .000 & $*$ \\
\hline Mental imagery strategies & 2.28 & 2.33 & .704 & \\
\hline Repetition strategies & 2.35 & 2.54 & .098 & \\
\hline Linking strategies & 2.72 & 2.87 & .118 & \\
\hline Kinaesthetic strategies & 1.28 & 1.32 & .518 & \\
\hline Guessing from context strategies & 2.76 & 2.55 & .129 & \\
\hline $\begin{array}{l}\text { Social strategies involving } \\
\text { teachers }\end{array}$ & 2.41 & 2.34 & .465 & \\
\hline $\begin{array}{l}\text { Social strategies involving } \\
\text { students }\end{array}$ & 2.67 & 2.44 & .122 & \\
\hline
\end{tabular}




\section{DISCUSSION}

In this section, I proceed to explore secondary-school learners' usage of vocabulary learning strategies. To do so, I focus on two main aspects: firstly, I explore the theoretical assumptions of the Schmitt's taxonomy that led to the six categories the author proposed. Then, having clarified the framework of analysis, I present first the selection of vocabulary learning strategies by secondary-school learners in general, and then those used by CLIL and mainstream EFL learners as separate groups.

The last part of the methodology section deals with a reconsideration of Schmitt's taxonomy, based on the evidence that the groups proposed did not show any internal coherence. Oxford (2017) states that learners group strategies in different ways based on their own preferences. Based on this premise, it was central to the interests of this study to explore how strategies relate. The factor analysis served this purpose. Results reveal the existence of eight categories, namely, lexical analysis, mental imagery, repetition, linking, kinaesthetic, guessing, and collaboration with teachers and classmates strategies.

This new classification allows analysis of learners' usage of the different categories. Of these, the preferred group was linking strategies. This group of strategies involves the use of word lists and bilingual dictionaries and the grouping of words to study them. This category seems to be related to the development of a network between Spanish and English words and secondary-school learners seem confident when using these strategies.

Conversely, the least widely used group was the kinaesthetic one. This group was made up only of one strategy, the use of physical actions when learning a word. This result is in line with other studies such as García López (2000), who stated that the sensorial strategies are barely used by secondary-school learners, or Schmitt (1997), who reported that this strategy ranked 36 in a list of 40 strategies. Two main explanations may be given to this finding: first, it could be related to the learning process itself: the higher the level of proficiency, the lower the level of concreteness is needed. In other words, as the level of the $\mathrm{L} 2$ increases, more abstract concepts are presented to learners, and it may become more difficult to represent those new ideas with movement. Second, the methodology employed in EFL classes could also explain this result: in Primary Education, movement is considered a need because of learners' characteristics, however, its use is relegated to a second place in higher levels.

These preferences were borne out with the analysis of the most and least widely used strategies. With respect to the preferred strategy, there was a strong affinity for checking for L1 cognates and use of word lists. This result did not 
match with previous studies. Lawson and Hogben (1996), García López (2000) and Schmitt (1997) concluded that the most widely used strategies were those which involved repetition techniques. Indeed, in the case of the cognates, Schmitt concluded that it was the least used strategy. This inconsistency may be related to the mother tongue of the learners. In Schmitt's study, the sample was made up of Japanese learners, unlike this study, with a sample consisting of Spanish learners. Spanish is a Romance language and shares more links with English than Japanese. In fact, they share the alphabet, so Spanish learners may not have the need to repeat the new words so frequently, as they are used to the letters. Moreover, some words in both languages may also have the same etymological origins, thus facilitating understanding and retention of the items in the foreign language. Therefore, it would make sense that Spanish learners resort to their mother tongue aiming to look for some kind of similarity.

As for the use of word lists, they have been consistently reported to be preferred in the majority of studies (Schmitt 1997). However, different cognitive theories, such as the Depth of Processing Hypothesis (Craik and Tulving 1975) or Bloom's taxonomy (1984), question their efficacy, as mechanical methods of repetition seem not to be as beneficial as other ways of teaching. Results in this area are inconclusive. On the one hand, researchers such as Griffin and Harley (1996), or Hoshino (2010) highlight the usefulness of using word lists for vocabulary acquisition. On the other hand, other studies such as Folse's (2004) cannot assert that word lists are neither detrimental nor beneficial when learning vocabulary. Therefore, an in-depth analysis of the influence of this strategy on vocabulary level would be welcome.

Finally, the last part of the results section deals with the differences between CLIL and EFL learners. In general, a greater use of strategies by CLIL learners was found. Although the difference between both groups of learners was not significant, it could be relevant for the purposes of study, as it may show a pattern. A review of the literature (Oxford and Nyikos 1989; Psaltou-Joycey and Kantaridou 2009; Vrettou 2009) often reveals a greater and more efficient use of strategies by more proficient learners. CLIL learners are often reported to outperform mainstream EFL learners in several language learning aspects such as vocabulary (Agustín-Llach and Canga Alonso 2016; Canga Alonso 2013, 2015), grammar (Machado Osado 2015) or language transfer (Agustín-Llach 2009). Under the assumption that CLIL learners are more proficient in language learning, it could be expected that they make greater use of strategies in the light of previous findings. Other reasons that may explain this finding could be the methodology employed and the teacher/s' role. Nation (2001) suggests that the teachers play a relevant role in the learning of vocabulary learning strategies, as they can present the learners with new ways 
of learning. As regards the two groups analysed, on the one hand, EFL students' ways of dealing with L2 vocabulary may be only influenced by the EFL teacher. On the other hand, CLIL learners are exposed to the influence of a number of teachers that use English to teach contents in a number of subjects. All those teachers may influence CLIL participant' learning process, fostering a wider range of techniques or strategies.

In relation to the differences in the use of word lists in favour of mainstream EFL participants, it has been already discussed how the use of these strategies affects vocabulary development. However, it seems that those learners exposed to a lower amount of L2 input - EFL learners - are more willing to make use of word lists than those who were exposed to a greater amount of input. It may be that, as the language input increases, more and more varied strategies come into play, diminishing the use of those strategies that initially were rooted in learners' minds.

As with word lists, differences were also found in favour of mainstream EFL learners in the use of written repetition strategies. This finding may be related to the use of the CLIL approach. CLIL promotes a greater cognitive engagement, that may result in a reduction of the use of repetition strategies, as they are considered less cognitively demanding tasks.

Significant differences were also found in favour of CLIL learners. CLIL learners selected significantly more often the analysis of affixes and roots, the use of English-language media and the connection with other synonyms and antonyms, therefore, differences are related to learners' attitude ('use of English-language media') and metalinguistic awareness ('antonyms and analysis of affixes and roots') and L2 linking ('connection of the word with synonyms and antonyms').

Starting with the discrepancies in the use of English-language media, it seems that CLIL learners make greater use of English-language media (such as TV, newspapers or books) as a way to learn new vocabulary items. A number of reasons may be attributed to this finding. First, there is evidence that CLIL learners have a better vocabulary size (Canga Alonso 2015; Jiménez Catalán and Ruiz de Zarobe 2009). If they know a larger number of words, they may feel better prepared to understand real English input, rather than the adapted one presented in the classroom. Secondly, there is also some research in the literature that suggests that CLIL learners are more motivated learners (Alejo and Piquer-Píriz 2016; Lasagabaster and López Beloqui 2015). If so, they may be more willing to learn English outside the classroom. Finally, there is also an extrinsic reason not really related to the learning process itself: most of the most fashionable series and films are first broadcast in English, so CLIL learners 
may feel the 'necessity' to watch that program in the original language and may feel more confident in comparison to EFL learners to understand and face this challenge.

As for the differences in lexical analysis strategies, CLIL participants presented a higher use of this group of strategies and this could be due to a number of reasons. First, CLIL learners are more exposed to English and this may result in capacity to reflect on properties of the language. Secondly, it could also be related to the fact that the use of this particular strategy may be related to a larger vocabulary size. If CLIL learners have a larger vocabulary size as alreadymentioned (Canga Alonso 2015; Castellano-Risco 2018; Jiménez Catalán and Ruiz de Zarobe 2009), they may make a greater use of this strategy.

Similarly, CLIL learners make significant more use of the 'connecting the word to its synonyms and antonyms' strategy. As with the previous strategy, this one is closely related to lexical analysis. However, it is also related to the learners' ability to create links within L2 words. This greater use by CLIL learners may be also related to the fact that CLIL learners are found to have a larger vocabulary size (Canga Alonso 2015; Jiménez Catalán and Ruiz de Zarobe 2009) and, as they have access to a larger number of words, they may be better able to create connections between L2 words.

Finally, some non-significant differences in the selection of vocabulary learning strategies also merit discussion. Such is the case of social strategies. Regardless of the group of social strategies studied, CLIL learners selected them more frequently than mainstream EFL participants. It may be related to the fact that CLIL promotes co-operative work, and so, it may result in a higher selection of strategies that imply other learners' or teachers' cooperation.

\section{CONCLUSION}

At the beginning of the present research study, two main objectives were established, so having analysed all the data, these main objectives can be summarized.

First of all, it seems that there is an underlying connection among the strategies. Analysis of how the use of strategies relates to other strategies resulted in the classification of the strategies into eight main categories, namely, lexical analysis, mental imagery, repetition, linking, kinaesthetic, guessing, and collaboration with teachers and classmates groups. Within these, in general, a preference was found towards creating links to learn new vocabulary items and a dislike of the use of strategies involving movement. In the case of the preferred strategy, this 
finding does not correspond with other studies in which repetition strategies were reported as the preferred one. However, at the same time, dismissal of the use of kinaesthetic strategies seems to be a constant pattern.

Finally, there is a clear distinction in the use of vocabulary learning strategies taking into account the type of instruction: CLIL learners made more use of strategies than mainstream EFL learners, probably due to the more varied role that the different teachers involved in the bilingual programme play. Moreover, CLIL learners make more use of some particular strategies, such as use of Englishlanguage media, analysis of affixes and roots and connection with synonyms and antonyms. Contrarily, they made significantly less use of word lists and written repetition strategies. Although this performance may be related to the influence of CLIL, the effect of other factors, such as teachers' influence, the quality of the input received or the amount of exposure to L2, could also partially explain the results.

These findings have clear implications for the language teaching practice. Particularly important is the reclassification of the items presented in Schmitt's taxonomy, as it constitutes a stronger framework of study, supported by empirical data. Moreover, once the most beneficial strategies are identified, vocabulary learning proposals, and teaching materials, could incorporate these findings. Finally, the analysis of strategy use can also yield relevant information about learners' performance and the influence of the use of different language teaching/ learning approaches on the vocabulary learning process.

The results need to be treated with caution, as there are a number of limitations with regard to them. First, the sample of this study is not overly big. Second, other variables should be considered when exploring the use of vocabulary learning strategies, such as learning styles or the influence of teachers and textbooks. Focusing on the teachers, it would be of great interest to analyse teachers' beliefs and speech, in order to examine the extent to which they may influence learners' choices. Finally, when working with secondary-school learners there is always some concern about the reliability of their answers. Although the maturational level of the participants was a factor taken into account when selecting the sample, it is possible that these learners may have been dishonest or were unable to reflect on how they learn.

At the same time, all these limitations can be considered the starting points for further research. As for the sample, further research on vocabulary learning strategies should include a larger and more varied sample. Moreover, a great contribution to the field would be the development of a taxonomy of language learners' vocabulary learning strategies in which the inclusion of the digital element, 
UNDERSTANDING THE SELECTION OF VOCABULARY LEARNING STRATEGIES...

so present in today's classes and learners' world, would, definitely, need to be considered. However, this is not the only change that should be contemplated in comparison to previous taxonomies, as this taxonomy should be inclusive and incorporate a number of improvements compared to its predecessors. First, the development of this taxonomy should, in my opinion, follow a similar pattern to Schmitt's development, and focus on teachers' and students' thoughts at the same time that materials are examined, but, including the findings of the previous research on vocabulary learning strategies. Moreover, it should also consider as a sample, not only tertiary learners, but also secondary-school learners, as in most of the occidental countries, they are FL learners per se, because they attend EFL subjects compulsory at school. With the inclusion of both kinds of learners, it could be possible to achieve a more embracing taxonomy and it could be better applied to subsequent research. Finally, the grouping of the different items identified should follow not only theoretical conceptualizations, but it should be necessarily supported with statistical analyses.

\section{REFERENCES}

Agustín-Llach, M. P. 2009. "The Role of Spanish L1 in the Vocabulary Use of CLIL and non-CLIL EFL Learners". Content and language integrated learning: Evidence from research in Europe. Eds. M. P. Agustín-Llach and R. M. Jiménez Catalán. UK: Multilingual Matters. 112-130.

Agustín-Llach, M. P. and A. Canga Alonso. 2016. "Vocabulary growth in young CLIL and traditional EFL learners: evidence from research and implications for education". International Journal of Applied Linguistics 26 (2): 211-227.

Alejo González, R. and A. Piquer Píriz 2010. "CLIL teacher training in Extremadura. A needs analysis perspective". CLIL in Spain. Implementation, Results and Teacher Training. Eds. D. Lasagabaster and Y. Ruiz de Zarobe. Cambridge: Cambridge Scholars Publishing. 219-242.

Alejo, R. and A. Piquer-Píriz. 2016. "Measuring the productive vocabulary of secondary school CLIL students: is Lex30 a valid test for low level school learners?". Vigo International Journal of Applied Linguistics 16: 31-53.

Anderson, R. C. and P. Freebody. 1981. "Vocabulary knowledge". Comprehension and teaching: research reviews. Ed. J. T. Guthrie. Newark, D.E.: International Reading Association. 77-117.

Arribas, M. 2016. "Analysing a whole CLIL school: Students' attitudes, motivation, and receptive vocabulary outcomes". Latin American Journal of Content and Language Integrated Learning 9 (2): 267-292. http://doi.org/10.5294/ laclil.2016.9.2.2. 
Azkarai A. and A. Imaz Agirre. 2016. "Negotiation of meaning strategies in child EFL mainstream and CLIL settings". TESOL Quarterly 50 (4): 844-870.

Bacon, S. M. 1992. "Phases of listening to authentic input in Spanish: a descriptive study". Foreign Language Annals 25: 317-334.

Barnett, M. 1989. More than Meets the Eye. Englewood Cliff, N. J.: Prentice Hall.

Bialystok, E. 1978. "A theoretical model of second language learning”. Language Learning 28 (1): 69-83.

Bialystok, E. 1981. "The role of conscious strategies in second language proficiency". Modern Language Journal 65: 24-35.

Bloom, B. S. 1984. Taxonomy of educational objectives. Boston: Allyn and Bacon.

Boers, F. and S. Lindstromberg. 2009. Optimizing a Lexical Approach to Instructed Second Language Acquisition. Basingstoke. Palgrave Macmillan.

Cameron, L. 2001. Teaching languages to young learners. Cambridge: Cambridge University Press.

Canale, M. 1983. "From Communicative Competence to Communicative Language Pedagogy". Language and Communication. Eds. J. C. Richards and R. Scchmidt. London: Logman. 2-27.

Canale, M. and M. Swain. 1980. "Theoretical Bases of Communicative Approaches to Second Language Teaching and Testing". Applied Linguistics 1: 1-47.

Canga Alonso, A. 2013. "The receptive vocabulary of 6th-grade primary-school students in CLIL instruction: A preliminary study". Latin American Journal of Content and Language Integrated Learning 6 (2): 22-41.

Canga Alonso, A. 2015. "Receptive Vocabulary of CLIL and Non-CLIL Primary and Secondary School Learners". Complutense Journal of English Studies 23: 59-77.

Castellano-Risco, I. 2018. "Receptive vocabulary and learning strategies in secondary school CLIL and non-CLIL learners”. Onomázein 40 (2): 28-48.

Cohen, A. D., Weaver, S. J. and T.-Y. Li. 1998. "The impact of strategies-based instruction on speaking a foreign language". Strategies in Learning and Using a Second Language. Ed. A. D. Cohen. 107-156.

Coxhead, A. 2000. "A new Academic Word List”. Tesol Quartely 34 (2): 213-239.

Craik, F. I. M. and E. Tulving. 1975. "Depth of processing and the retention of words in episodic memory". Journal of Experimental Psychology 104 (3): 268-294.

Ehrman, M., Leaver, B. and R. Oxford. 2003. "A brief overview of individual differences in second language learning”. System 31: 313-330.

Folse, K. S. 2004. "Myths about teaching and learning second language vocabulary: what recent research says". TESL Reporter 37 (2): 1-13. 
UNDERSTANDING THE SELECTION OF VOCABULARY LEARNING STRATEGIES...

García López, M. 2000. "Estrategias de aprendizaje de vocabulario de inglés utilizadas por los estudiantes de secundaria”. Lenguaje y Textos 15: 61-70.

Griffin, G. and T. A. Harley. 1996. "List learning of second language vocabulary". Applied Psycholinguistics 17: 443-460.

Gu, Y. and R. K. Johnson. 1996. "Vocabulary Learning Strategies and Language Learning Outcome". Language Learning 46: 643-679.

Hayati, A. M. 2005. "A comparative study of using bilingual and monolingual dictionaries in reading comprehension of intermediate EFL students". The Reading Matrix 5 (2): 61-66.

Hoshino, Y. 2010. "The Categorical Facilitation Effects on L2 Vocabulary Learning in a Classroom Setting". RELC Journal 41 (3): 301-312.

Intaraprasert, C. 2004. EST Students and Vocabulary learning strategies: A preliminary investigation. Muang: Suranaree University of Technology, School of English.

Jiménez Catalán, R. M. 2003. "Sex differences in L2 vocabulary learning strategies". International Journal of Applied Linguistics 12 (1): 54-77.

Jiménez Catalán, R. M. and Y. Ruiz de Zarobe. 2009. "The receptive vocabulary of EFL learners in two instructional contexts: CLIL versus non-CLIL learners". Content and Language Integrated Learning: Evidence from research in Europe. Eds. Y. Ruiz de Zarobe and R. M. Jiménez Catalán. UK: Multilingual Matters. 81-93.

Lasagabaster, D. and R. López Beloqui. 2015. "The Impact of Type of Approach (CLIL Versus EFL) and Methodology (Book-Based Versus Project Work) on Motivation". Porta Linguarum 23: 41-57.

Laufer, B. 1990. "Why are some words more difficult than others? Some intralexical factors that affect the learning of words". International Review of Applied Linguistics in Language Teaching 28: 293-307.

Laufer, B. and P. Nation. 1999. "A vocabulary-size test of controlled productive ability”. Language Testing 16 (1): 33-51.

Lawson, M. J. and D. Hogben. 1996. The Vocabulary-Learning Strategies of ForeignLanguage Students. Language Learning 46 (1): 101-135.

Machado Osado, P. 2015. The role of CLIL learners' aptitude when learning an L2 in Extremadura: Study of the interrelationship between language aptitude, L2 productive vocabulary and grammar in Secondary school. Unpublished M. A. dissertation. Universidad de Extremadura: Spain.

Manchón, R. M. 2001. "Trends in the conceptualisations of second language composing strategies: A critical analysis". International Journal of English Language Studies 1 (2): 47-70. 
Martín Leralta, S. 2006. "La integración de la competencia estratégica en el currículo de lengua inglesa". ELUA 20: 233.257.

Martínez Adrián, M., Gallardo del Puerto, F. and M. Basterrechea. 2019. "On self-reported use of communication strategies by CLIL learners in primary education". Language Teaching Research 23 (1): 39-57.

Meara, P. 1980. "Vocabulary acquisition: a neglected aspect of language learning". Language Teaching and Linguistics: Abstracts 13 (4): 221-246.

Meara, P. 1996a. "The dimensions of lexical competence". Performance and Competence in Second Language Acquisition. Eds. G. Brown, K. Malmkjaer, and J. William. Cambridge: Cambridge University Press. 35-53.

Meara, P. 1996b. The vocabulary knowledge framework. Vocabulary Acquisition Research Group Virtual Library.

Meara, P. 2010. EFL vocabulary tests (2nd ed.). Wales University: Swansea Centre for Applied Language Studies.

Milton, J. and T. Fitzpatrick. 2014. Dimensions of vocabulary knowledge. UK: Palgrave Macmillan.

Nation, I. S. P. 1974. "Techniques for teaching vocabulary". English Teaching Forum 12 (3): 18-21.

Nation, I. S. P. 2001. Learning Vocabulary in Another Language. Cambridge: Cambridge University Press.

Nation, P. 2005. "Teaching Vocabulary". Asian EFL Journal 7 (3): 47-54.

Nunnally, J. C. 1978. Psychometric theory. 2nd Edition. New York: McGraw-Hill.

O'Malley, J. and A. U. Chamot. 1990. Learning Strategies in Second Language Acquisition. Cambridge: Cambridge University Press.

Oxford, R. 1989. "Use of Language Learning Strategies: a synthesis of studies with implications for strategy training". System 17 (2): 235-247.

Oxford, R. 1990. Language Learning Strategies. New York: Newbury House.

Oxford, R. 2017. Teaching and Researching Language Learning Strategies: selfregulation in Context (2nd ed.). New York: Routledge.

Oxford, R. and M. Nyikos. 1989. "Variables affecting choice of language learning strategies by university students". The Modern Language Journal 83 (3): 291300 .

Politzer, R. L. 1983. "An Exploratory Study of Self Reported Language Learning Behaviors and their Relation to Achievement". Studies in Second Language Acquisition 6 (1): 54-68. https://doi.org/10.1017/S0272263100000292. 
Psaltou-Joycey, A. and Z. Kantaridou. 2009. "Plurilingualism, language learning strategy use and learning style preferences". International Journal of Multilingualism 39: 460-474.

Richards, J. C. 1976. "The role of vocabulary teaching”. TESOL Quaterly 10: 77-89.

Rubin, J. 1987. "Learner strategies: theoretical assumptions, research history and typology". Learner Strategies in Language Learning. Eds. A. L. Wenden and J. Rubin. New York: Prentice Hall. 15-30.

Schmitt, N. 1995. "A fresh approach to vocabulary using a word knowledge framework". RELC Journal 26 (1): 86-94.

Schmitt, N. 1997. "Vocabulary learning strategies". Vocabulary: Description, acquisition and pedagogy. Eds. N. Schmitt and M. McCarthy. Cambridge University Press: Cambridge. 199-227.

Schmitt, N. 2010. Researching vocabulary: A Vocabulary Research Manual. Palgrave Press.

Schmitt, N., Schmitt, D. and C. Claphman. 2001. "Developing and exploring the behaviour of two new versions of the Vocabulary Levels Tests". Language Testing 18 (1): 55-88.

Stöffer, I. 1995. University foreign language students' choice of vocabulary learning strategies as related to individual difference variable. Unpublished $\mathrm{Ph}$. D. Thesis. University of Alabama: U.S.A.

Trenchs, M. 1996. "Writing strategies in a second language: Three case studies of learners using electronic mail". Canadian Modern Language Review 52: 464497.

Vandergrift, L. 1997. "The strategies of second language (French) listeners: A descriptive study". Foreign Language Annals 30: 387-409.

Vrettou, A. 2009. "Language learning strategy employment of EFL Greek-speaking learners in junior high school”. Journal of Applied Linguistics 25: 85-106.

Wenden, A. 1991. Learner strategies for learner autonomy. Prentice Hall.

Wenden, A. and J. Rubin. 1987. Learner strategies in language learning. Hemel Hempstead: Prentice Hall.

Xue, G. and N. Nation. 1984. "A university word list". Language Learning and Communication 3 (2): 215-229. 